TITLE:

\title{
Epidemiology of Birth Defects in Very Low Birth Weight Infants in Japan(Abstract_要旨)
}

$\operatorname{AUTHOR}(S)$ :

Kawasaki, Hidenori

\section{CITATION:}

Kawasaki, Hidenori. Epidemiology of Birth Defects in Very Low Birth Weight Infants in Japan. 京都大学, 2020, 博士(医学)

ISSUE DATE:

2020-11-24

URL:

https://doi.org/10.14989/doctor.r13379

\section{RIGHT:}

doi: https://doi.org/10.1016/j.jpeds.2020.07.012. (c) 2020. This manuscript version is made available under the CC-BY-NC-ND 4.0 license http://creativecommons.org/licenses/by-nc-nd/4.0/ 


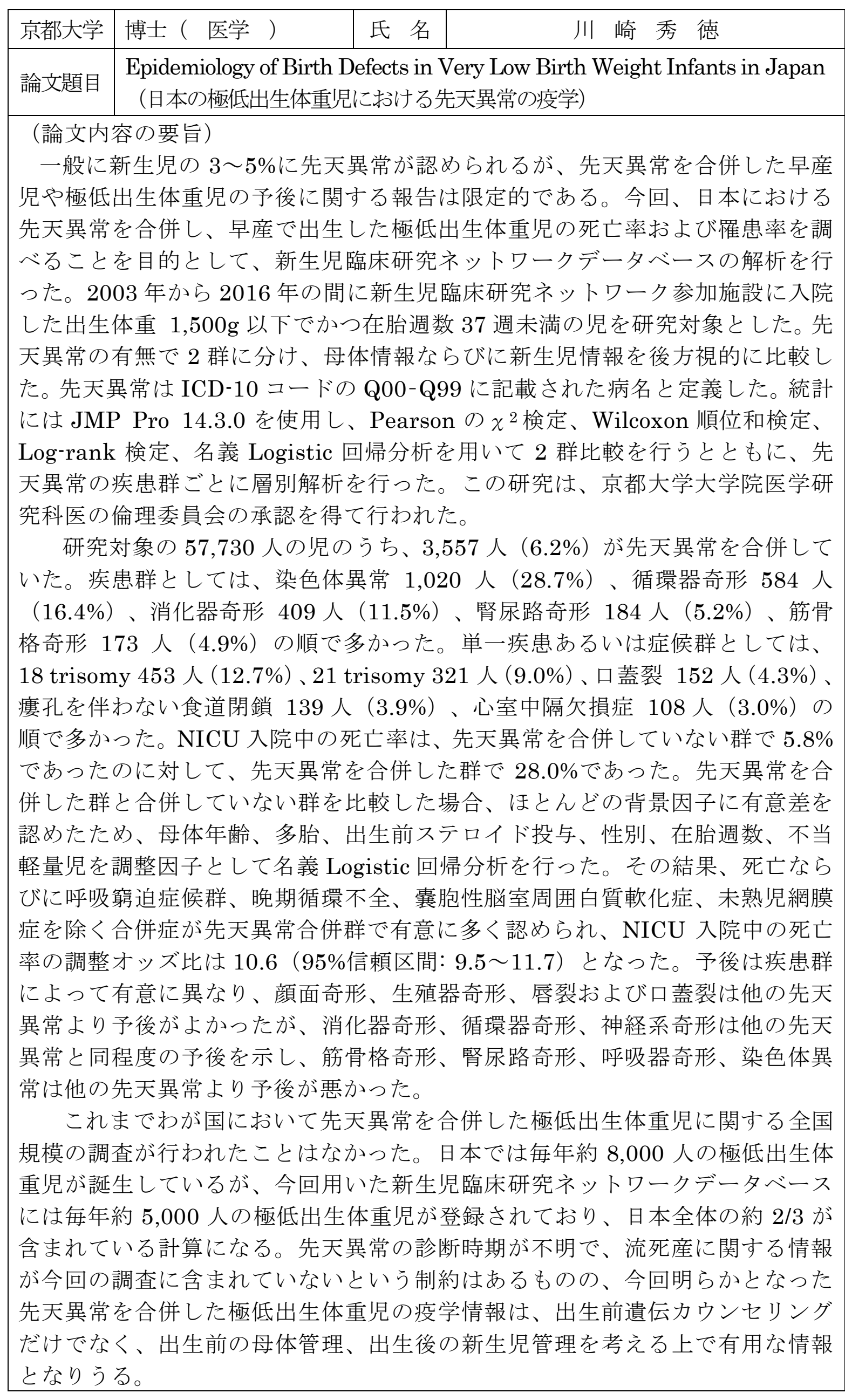

（論文審査の結果の要旨）

日本における先天異常を合併した極低出生体重児の短期予後を明らかにする ことを目的として、大規模疫学調查を行った。

2003 年から 2016 年の間に新生児臨床研究ネットワークデータベース参加施 設に入院した出生体重 $1500 \mathrm{~g}$ 以下、在胎週数 37 週未満の览を対象とした。 ICD-10 コードの Q00-Q99 を先天異常と定義した。解析には JMP Pro 14.3.0 を使用し、Pearson $\chi^{2}$ 検定、Wilcoxon 順位和検定、Log-rank 検定、名義 Logistic 回帰分析、サブグループ解析を行った。この研究は、京都大学大学院医学研究 科医の倫理委員会の承認を得て行われた。

対象の 57,730 人のうち、3,557人 $(6.2 \%)$ に先天異常を認めた。疾患群と ては染色体異常、循環器奇形、消化器奇形の順に多く、単一疾患女るいは症候 群としては 18 トリソミー、21トリソミー、口蓋裂の順に多かった。NICU 入 院中の死亡率は先天異常のある児とない児でそれぞれ $28.0 \%$ と $5.8 \%$ あった。 母体年齢、多胎、出生前ステロイド、性別、在胎週数、不当軽量児を説明变数 として先天異常の有無で名義 Logistic 回帰分析を行った結果、ほとんどの合併 症が先天異常のある览で有意に多く、NICU 入院中の死亡率の調整オッズ比は 10.6（95\%信頼区間：9.5～11.7） となった。他の先天異常群と比較して、予後 が有意に良好な群、同程度の群、不良の群の 3 群に分類した。

先天異常の診断時期が不明で、流死産に関寸る情報が含まれていないという 制約はあったが、今回明らかとなった疫学情報は、出生前遺伝カウンセリング、 母体管理、新生览管理を考える上で有用な情報となりうる。

以上の研究は日本における先天異常を合併した極低出生体重児の疫学情報を 提供し、周産期医療に寄与すると考えられる。 認める。

したがって、本論文は博士（医学）の学位論文として価値あるものと なお、本学位授与申請者は、令和 2 年 9 月 24 日実施の論文内容とそれに 関連した研究分野並びに学識確認のための試問を受け、合格と認められたもの である。 